\title{
RAÎNSTEK \\ PENERAPAN STRATEGI QUESTION STUDENTS HAVE (QSH) TERHADAP PRESTASI BELAJAR
}

\author{
Yunita Army Wahyuningtias ${ }^{1}$, Sri Hariyani ${ }^{2}$, Riski Nur Istiqomah Dinnullah ${ }^{3}$ \\ Program Studi Pendidikan Matematika Universitas Kanjuruhan Malang ${ }^{1,2,3}$ \\ yuenitha.024@gmail.com ${ }^{1}$, srihariyani@unikama.ac.id ${ }^{2}$,ky2_zahra@unikama.ac.id ${ }^{3}$
}

\begin{abstract}
Abstrak. Penelitian ini bertujuan untuk mengkaji penerapan strategi pembelajaran Question Students Have (QSH) yang dapat meningkatkan prestasi belajar matematika siswa kelas IX SMPN 2 Karangploso Satu Atap. Prosedur pengambilan data pada penelitian ini meliputi observasi, tes, dan angket. Teknik analisis data menggunakan cara reduksi data, penyajian data, dan penarikan kesimpulan. Langkah-langkah strategi pembelajaran Question Student Have (QSH) yang dapat meningkatkan prestasi belajar matematika adalah: (1) guru membagikan LKK kepada masing-masing kelompok, (2) guru menyampaikan materi pembelajaran, (3) guru memberikan potongan kertas kepada masing-masing siswa, (4) siswa menuliskan pertanyaan pada potongan kertas, (5) siswa membacakan pertanyaan sampai pertanyaan pada potongan kertas masing-masing siswa terbaca semua, dan (6) guru dan siswa menyimpulkan materi yang sudah dipelajari. Hasil analisis data menunjukkan nilai rata-rata hasil tes siswa pada tindakan I mencapai 70,26 dengan persentase ketuntasan $66,6 \%$. Sedangkan pada tindakan II, nilai rata-rata hasil tes siswa mencapai 82,65 dengan persentase ketuntasan 91,6\%. Hasil aktivitas siswa pada tindakan I pertemuan 1 mendapat persentase $77,27 \%$ dan pada pertemuan 2 mendapatkan persentase $78,12 \%$. Pada tindakan II, hasil aktivitas siswa pada pertemuan 1 mendapat persentase $81,81 \%$ dan hasil aktivitas siswa pada pertemuan 2 mendapat persentase $86,66 \%$. Jadi disimpulkan bahwa penerapan strategi Question Students Have (QSH) dapat meningkatkan prestasi belajar siswa.
\end{abstract}

Kata Kunci: Strategi Question Student Have (QSH); prestasi belajar matematika

\section{PENDAHULUAN}

Pendidikan adalah interaksi antara faktor-faktor yang terlibat di dalamnya guna mencapai tujuan pendidikan (Ramdhani, 2014:30). Pendidikan diharapkan dapat menjadikan perubahan dalam berbagai aspek dan teknologi yang begitu pesat, serta globalisasi yang melanda dunia termasuk bangsa Indonesia. Melalui perubahan itu, dunia pendidikan dituntut mampu memberikan kontribusi nyata berupa peningkatan kualitas hasil dan pelayanan pendidikan kepada masyarakat. Hal yang perlu diperhatikan dalam upaya peningkatan kualitas pendidikan adalah penyelenggaraan proses pembelajaran. Selain itu, guru sebagai pelaksana pendidikan memegang peranan yang sangat penting dalam keberhasilan proses pembelajaran. Faktor lain juga memiliki peran penting seperti siswa, bahan pelajaran, motivasi, dan sarana penunjang lainnya. Oleh karena itu, inovasi dan kreativitas guru sebagai ujung tombak berhasil tidaknya pendidikan dalam meningkatkan kualitas kehidupan manusia mutlak diperlukan, salah satu bentuknya adalah dengan melakukan pembaharuan strategi dalam pembelajaran.

Berdasarkan hasil observasi, guru matematika belum menerapkan strategi pembelajaran dalam kegiatan pembelajaran, selain itu hasi belajar siswa masih banyak yang di bawah KKM. Hasil observasi menunjukkan nilai rata-rata hasil tes siswa adalah 65,4 dengan persentase ketuntasan belajar mencapai $41,6 \%$, sehingga peneliti tertarik untuk menerapkan strategi pembelajaran untuk meningkatkan prestasi belajar siswa. Dari beberapa strategi pembelajaran, ada salah satu yang menurut peneliti dapat mengatasi masalah tersebut. Strategi yang dimaksud adalah Question Students Have (QSH) yang bertujuan untuk mengoptimalkan penggunaan semua potensi yang dimiliki anak didik, sehingga semua anak didik dapat mencapai prestasi belajar yang memuaskan. Strategi pembelajaran Question Students Have (QSH) mewajibkan siswa untuk mengungkapkan masalah tentang materi pelajaran yang kurang dipahami. 
Pembelajaran dengan strategi ini dapat menghilangkan rasa malu siswa untuk bertanya serta sulit mengkomunikasikan pertanyaan secara lisan.

Strategi Question Students Have (QSH) adalah strategi pembelajaran aktif yang mengharuskan peserta didik aktif bertanya dan mengemukakan gagasan (Bahri, 2012:47). Menurut Nisa (2015:2) dalam strategi ini, siswa diberikan potongan kertas kosong, kemudian siswa diminta untuk menuliskan pertanyaan yang mereka miliki tentang materi pelajaran. Setelah selesai membuat pertanyaan, siswa diminta untuk memberikan pertanyaan kepada teman di sampingnya. Sesudah mendapat kertas pertanyaan dari teman disampingnya, siswa diminta untuk memberi tanda centang jika pertanyaan tersebut perlu untuk ditannyakan dan jika tidak perlu ditanyakan maka siswa diminta untuk memberi tanda strip. Setelah kertas kembali kepada pemiliknya, guru meminta siswa untuk mengumpulkan kertas tersebut. Kemudian guru meminta siswa membacakan pertanyaan yang mendapat tanda centang paling banyak. Untuk mengimplementasikan pembelajaran strategi Question Students Have (QSH) di dalam kelas, peneliti menggunakan metode diskusi yang bertujuan memberikan kesempatan kepada tiap-tiap siswa untuk mengembangkan kemampuan memecahkan masalah sebelum mereka bertanya (Vianata, 2012:3). Strategi Question Students Have (QSH) yang diterapkan akan dapat menciptakan siswa yang aktif dalam belajar, sebab pada strategi ini setiap siswa dituntut untuk membuat pertanyaan sehingga perhatian siswa terpusat pada materi yang sedang dipelajari. Penerapan strategi Question Students Have (QSH) dalam pembelajaran matematika ini diharapkan dapat meningkatkan prestasi belajar matematika siswa.

Penelitian terdahulu mengenai Strategi pembelajaran Question Students Have (QSH) antara lain Yusri (2015:66) meneliti penerapan Strategi Question Students Have untuk mengetahui persentase aktivitas belajar siswa. Yusri (2015:66) melaporkan persentase aktivitas siswa selama empat kali pertemuan cenderung meningkat. Adapun aktifitas yang diamati yaitu siswa tetap berada dalam kelompok selama mengerjakan latihan, pengamatan pertama $63,89 \%$, pengamatan kedua $69,44 \%$, pengamatan ketiga $77,78 \%$, dan pengamatan keempat $88,89 \%$. Partisipasi siswa dalam kegiatan kelompok, pengamatan pertama $22,22 \%$, pengamatan kedua $38,89 \%$, pengamatan ketiga 47,22\%, dan pengamatan keempat $66,67 \%$. Penyampaian ide terhadap penyelesaian masalah dalam kelompok, pengamatan pertama $27,78 \%$, pengamatan kedua $41,67 \%$, pengamatan ketiga $58,33 \%$, dan pengamatan keempat $72,22 \%$. Pemberian tanggapan pertanyaan atau permasalahan anggota kelompok, pengamatan pertama 16,67\%, pengamatan kedua $30,56 \%$, pengamatan ketiga $13,89 \%$, dan pengamatan keempat $50,00 \%$. Pertanggungan jawab terhadap tugas, pengamatan pertama 58,33\%, pengamatan kedua 80,56\%, pengamatan ketiga $75,00 \%$, dan pengamatan keempat $88,89 \%$. Tepat waktu dalam menyelesaikan tugas, pengamatan pertama 66,67 , pengamatan kedua $88,89 \%$, pengamatan ketiga 50,00\%, dan pengamatan keempat 75,00\%.

Selanjutnya, Aminudin (2017:438-439) meneliti penerapan model pembelajaran kooperatif tipe Question Students Have (QSH) untuk meningkatkan hasil belajar. Aminudin (2017:438-439) melaporkan hasil belajar matematika pada siklus I dengan rata-rata nilai 68,7. Sedangkan ketuntasan sebesar 55,6 \% (20 anak tuntas) dan 44,4\% (10 anak tidak tuntas). Pada siklus II dengan nilai rata-rata 81,2 sedangkan ketuntasan sebesar 70\% (27 anak tuntas) dan 30\% (3 anak tidak tuntas). Firdaus (2018:7) meneliti efektivitas pembelajaran dengan Metode Question Students Have (QSH) Setting Kooperatif. Firdaus (2018:7) melaporkan hasil belajar matematika yaitu rata-rata nilai yang diperoleh 79,65 dan secara inferensial terpenuhi, secara deskriptif yaitu sebesar 0,63 (berada dalam kategori sedang) dan secara inferensial sebesar 5\% juga dikatakan terpenuhi. Penelitian ini berbeda dengan penelitian sebelumnya. Pada penelitian sebelumnya Question Students Have (QSH) diterapkan untuk mengetahui persentesase siswa dalam aktivitas belajar, peningkatan hasil belajar dan efektivitas yang dilakukan secara individu. Sementara pada penelitian ini Question Students Have (QSH) diterapkan untuk mengukur prestasi belajar siswa yang dilakukan secara berkelompok.

Berdasarkan permasalahan di atas, tujuan penelitian ini adalah untuk mendeskripsikan penerapan strategi Question Students Have (QSH) yang dapat meningkatkan prestasi belajar siswa dalam pembelajaran matematika pada pokok bahasan bangun ruang sisi lengkung kelas IX SMPN 2 Karangploso Satu Atap. 


\section{METODE PENELITIAN}

Penelitian ini merupakan penelitian tindakan kelas (Classrom Action Research) yang bertujuan untuk memperbaiki suatu keadaan pembelajaran di kelas dan memberikan tindakantindakan sebagai usaha untuk meningkatkan prestasi belajar siswa dalam belajar matematika. Penelitian tindakan kelas ini merupakan kegiatan pemecahan masalah atas prestasi belajar siswa yang rendah untuk diselidiki tingkat kelebihan atau kelemahan terhadap tindakan perbaikan tersebut. PTK bercirikan perbaikan terus menerus sehingga kepuasan peneliti menjadi tolak ukur berhasilnya siklus-siklus tersebut. Penelitian tindakan kelas dalam penelitian ini menggunakan strategi Question Students Have (QSH) untuk meningkatkan prestasi belajar matematika pada bangun ruang sisi lengkung.

Pelaksanaan Penelitian Tindakan Kelas ini menggunakan strategi Question Students Have (QSH) yang dilakukan melalui beberapa siklus terdiri dari empat tahap, yaitu: (1) perencanaan, (2) pelaksanaan, (3) pengamatan, (4) refleksi. Untuk menentukan jumlah siklus, peneliti harus melihat tingkat keberhasilan dari siklus yang sudah dilakukan. Apabila dalam siklus I proses pembelajaran sudah mencapai tujuan yang diharapkan, maka peneliti cukup menggunakan satu siklus saja. Tetapi apabila dalam siklus I masih terdapat kekurangan dan perlu adanya perbaikan, maka peneliti perlu melanjutkan pada siklus berikutnya.

Subyek yang diteliti adalah siswa kelas kelas IX SMPN 2 Karangploso Satu Atap.Siswa tersebut yang berjumlah 12 siswa. Pelaksanaan penelitian dilaksanakan di kelas IX SMPN 2 Karangploso Satu Atap pada semester 1 tahun ajaran 2017-2018.Mata pelajaran yang diteliti adalah matematika dengan pokok bahasan materi bangun ruang sisi lengkung pada semester 1 tahun ajaran 2017-2018. Perangkat pembelajaran dalam penelitian ini meliputi standar kompetensi, kompetensi dasar, indikator, tujuan pembelajaran, bahan ajar, strategi pembelajaran, media dan sumber belajar, langkah-langkah pembelajaran, dan evaluasi. Teknik analisa data dalam penelitian ini meliputi (1) reduksi data, (2) penyajian data, dan (3) penarikan kesimpulan.

Prosedur pengumpulan data dalam penelitian ini meliputi (1) observasi dilakukan oleh peneliti dan pengamat untuk mengamati kesesuaian antara perangkat pembelajaran dan pelaksanaan tindakan, (2) studi dokumentasi yaitu cara memperoleh data tentang prestasi belajar sebelum dilakukan tindakan I yang diperoleh melalui data dokumentasi nilai ulangan harian siswa, (3) angket yaitu teknik pengumpulan data yang dilakukan dengan cara memberi seperangkat pertanyaan atau pernyataan tertulis kepada responden untuk dijawab, dan (4) tes yaitu dilakukan dengan tujuan untuk melihat prestasi belajar siswa setelah pemberian tindakan pembelajaran. Tes dilakukan pada akhir masing-masing tindakan. Sedangkan, prosedur pelaksanaan tindakan dalam penelitian ini mengikuti model yang telah dikembangkan oleh Kemmis dan Mc. Taggart berdasarkan atas konsep pokok bahwa Penelitian Tindakan Kelas (PTK) terdiri dari 4 komponen pokok dengan hubungan keempat komponen pokok tersebut menunjukkan tindakan yang dapat digambarkan dalam bagan berikut (Arikunto,2010:132). 


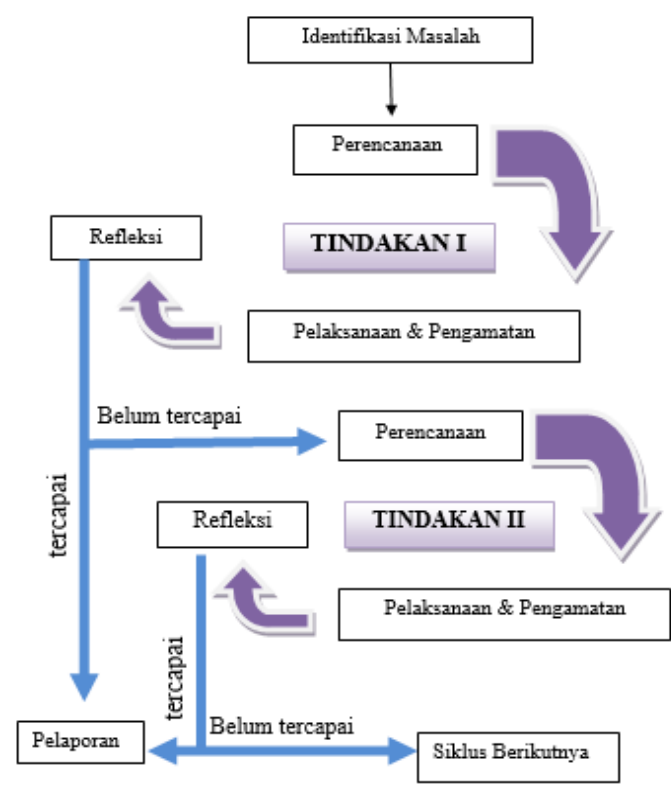

Gambar 1. Penelitian Tindakan Kelas (Classroom Actioan Research) (Sumber: Arikunto, 2010: 132)

\section{HASIL DAN PEMBAHASAN \\ Pratindakan}

Berdasarkan observasi awal, pada saat guru mata pelajaran menyampaikan materi dengan menggunakan metode demontrasi dan ceramah, siswa banyak yang mengantuk dan bicara sendiri, tidak mendengarkan guru saat menjelaskan, dan siswa tidak menunjukan rasa ingin tahu terhadap penjelasan guru. Berdasarkan dokumentasi yang diperoleh dari nilai raport, nilai rata-rata prestasi belajar siswa kelas IX adalah $41,6 \%$, nilai tersebut tidak memenuhi kriteria ketuntasan minimum (KKM) yang ditetapkan sekolah yaitu 75. Dari 12 siswa yang mencapai ketuntasan hanya 5 siswa dan siswa yang tidak tuntas adalah 7 siswa.

\section{Tindakan 1}

Hasil observasi aktivitas guru yang dilakukan pengamat I terhadap aktivitas penelitian pada pertemuan 1 diperoleh skor 36 dari skor maksimal 44. Dengan persentase rata-ratanya adalah $81,81 \%$. Untuk pertemuan 2 diperoleh skor 27 dari skor maksimal 32, dengan persentase rata-ratanya adalah $84,37 \%$. Dengan demikian pertemuan 1 dan pertemuan 2 sesuai dengan kriteria keberhasilan, maka dalam kegiatan pembelajaran dapat dikategorikan baik. Hasil observasi aktivitas siswa yang dilakukan pengamat I terhadap aktivitas penelitian pada pertemuan 1 diperoleh skor 34 dari skor maksimal 44. Dengan persentase rata-ratanya adalah $77,27 \%$. Untuk pertemuan 2 diperoleh skor 25 dari skor maksimal 32, dengan persentase rataratanya adalah $78,12 \%$. Dengan demikian pertemuan 1 dan pertemuan 2 sesuai dengan kriteria keberhasilan sehingga kegiatan pembelajaran dikategorikan baik.

Tabel 1. Aktivitas Guru Tindakan I

\begin{tabular}{ccc}
\hline Pertemuan & Presentase & Kriteria Keberhasilan \\
\hline Pertemuan 1 & $81,81 \%$ & Sangat Baik \\
Pertemuan 2 & $84,37 \%$ & Sangat Baik \\
\hline
\end{tabular}


RAINSTEK (Jurnal Terapan Sains \& Teknologi)

Fakultas Sains dan Teknologi - Universitas Kanjuruhan Malang

Vol. 2, No.2, 2020

Tabel 2. Aktivitas Siswa Tindakan I

\begin{tabular}{ccc}
\hline Pertemuan & Presentase & Kriteria Keberhasilan \\
\hline Pertemuan 1 & $77,27 \%$ & Baik \\
Pertemuan 2 & $78,12 \%$ & Baik \\
\hline
\end{tabular}

Berdasarkan identifikasi subjek 1, didapat kesimpulan bahwa subjek mengalami miskonsepsi pada soal 1 dan 3, dan menjawab dengan menebak pada soal nomor 4. Berdasarkan identifikasi subjek tersebut, pada soal nomor 1 subjek 1 belum memahami pengertian koefisien. Pemahaman subjek 1 untuk koefisien tertuju pada suku pada persamaan. Adapun pada soal nomor 3, subjek 1 mengalami miskonsepsi pada operasi pembagian bilangan positif dan negatif yang berada pada ruas yang berbeda. Pada saat wawancara, subjek 1 mengatakan bahwa bilangan negatif yang menjadi pembagi mengalami perubahan tanda yaitu menjadi positif. Subjek 1 menjawab dengan menebak pada soal nomor 4 dikarenakan belum memahami penyelesaian model matematika. Adapaun pada soal nomor 2, subjek 1 mengalami konsepsi ilmiah atau paham konsep.

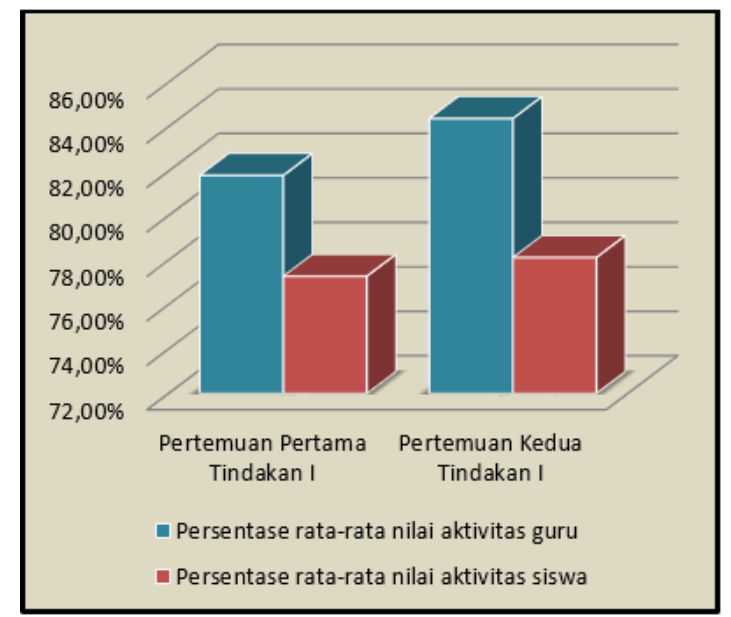

Gambar 2. Persentase Rata-rata Nilai Aktivitas Guru dan Siswa Tindakan I

Hasil tes akhir tindakan I mengalami peningkatan yaitu pada saat pra tindakan 65,4 dan tindakan I mencapai 70,8. Pembelajaran dengan menggunakan strategi Question Students Have (QSH) pada penelitian tindakan I dapat menjadikan prestasi belajar siswa meningkat.

Tabel 3. Hasil Tes Tindakan I

\begin{tabular}{ccc}
\hline Uraian & Pra Tindakan & Tindakan I \\
\hline Nilai rata-rata & 65,4 & 70,8 \\
KKM & 75 & 75 \\
Siswa yang memenuhi KKM & 5 siswa & 8 siswa \\
Ketuntasan belajar siswa & $41,6 \%$ & $66,6 \%$ \\
\hline
\end{tabular}




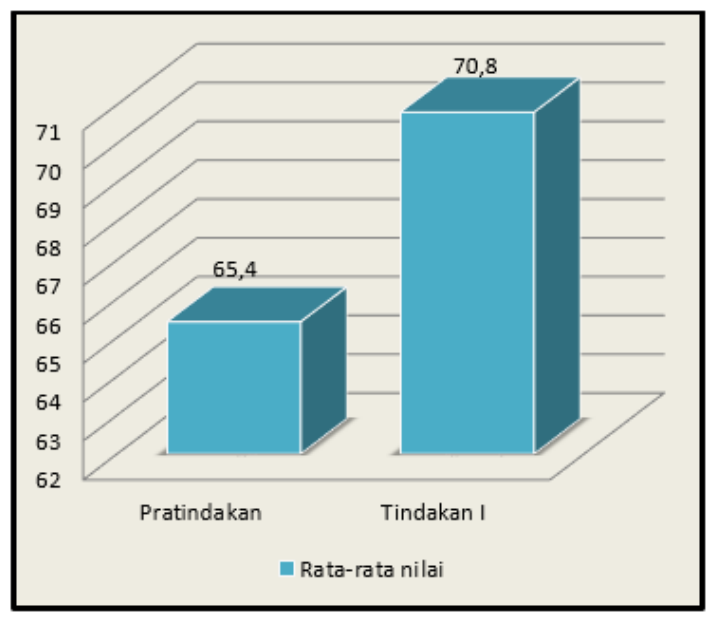

Gambar 3. Rata-rata Nilai Prestasi Belajar Siswa Tindakan I

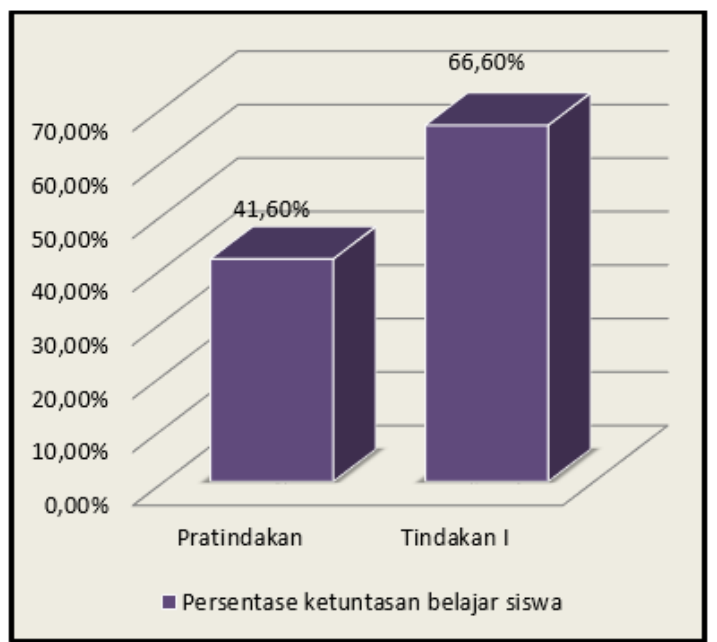

Gambar 4. Persentase Ketuntasan Prestasi Belajar Siswa Pra Tindakan dan Tindakan I

\section{Tindakan II}

Hasil observasi aktivitas guru yang dilakukan pengamat I terhadap aktivitas penelitian pertemuan 1 diperoleh skor 37 dari skor maksimal 44 dengan persentase 84,09\%, untuk pertemuan 2 diperoleh skor 28 dari skor maksimal 32 dengan prosentase 87,50\%. Dengan demikian persentase rata-rata telah sesuai dengan kriteria keberhasilan dan kegiatan pembelajaran dapat dikategorikan sangat baik. Hasil observasi yang dilakukan pengamat II terhadap aktivitas siswa pada pertemuan 1 diperoleh skor 36 dari skor total 44 dengan persentase rata-rata adalah $81,81 \%$, untuk pertemuan 2 diperoleh skor 26 dari skor total 32 dengan persentase rata-rata adalah $81,25 \%$. Dengan demikian persentase rata-rata telah sesuai dengan kriteria keberhasilan dan aktivitas siswa dalam pembelajaran dikategorikan sangat baik.

Tabel 4. Aktivitas Guru Tindakan II

\begin{tabular}{rcc}
\hline Pertemuan & Presentase & Kriteria Keberhasilan \\
\hline Pertemuan 1 & $84,09 \%$ & Sangat Baik \\
Pertemuan 2 & $87,50 \%$ & Sangat Baik \\
\hline & & \\
Tabel 5. Aktivitas Siswa Tindakan II \\
\hline Pertemuan & Presentase & Kriteria Keberhasilan \\
\hline Pertemuan 1 & $81,81 \%$ & Sangat Baik \\
Pertemuan 2 & $81,25 \%$ & Sangat Baik \\
\hline
\end{tabular}




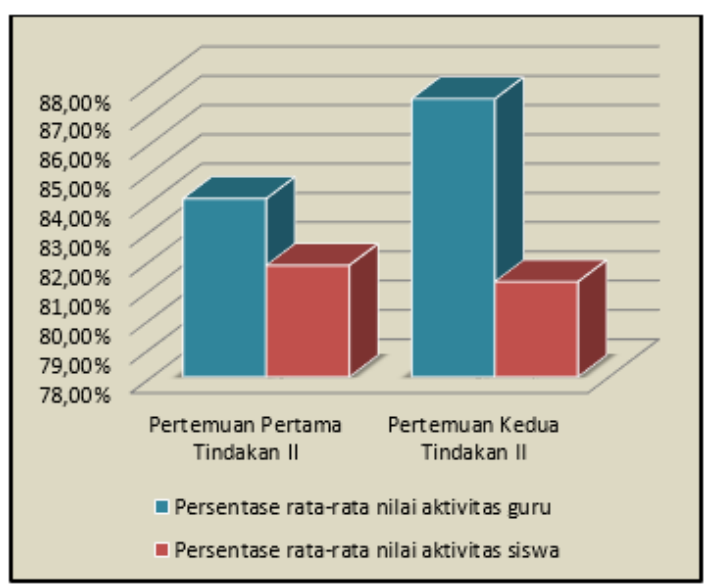

Gambar 5. Persentase Rata-rata Nilai Aktivitas Guru dan Siswa Tindakan II

Hasil tes tindakan I dan tindakan II mengalami peningkatan yaitu pada saat pra tindakan 65,4, meningkat pada tindakan I yaitu 70,8 dan tindakan II yaitu 82,5. Pembelajaran dengan menggunakan strategi Question Students Have (QSH) pada tindakan II dapat menjadikan prestasi belajar siswa meningkat.

Tabel 6. Hasil Tes Pra Tindakan, Tindakan I dan Tindakan II

\begin{tabular}{cccc}
\hline Uraian & Pra Tindakan & Tindakan I & Tindakan II \\
\hline Nilai rata-rata & 65,4 & 70,8 & 82,5 \\
KKM & 75 & 75 & 75 \\
Siswa yang memenuhi & 5 siswa & 8 siswa & 11 siswa \\
KKM & & & \\
Ketuntasan belajar siswa & $41,6 \%$ & $66,6 \%$ & $91,6 \%$ \\
\hline
\end{tabular}

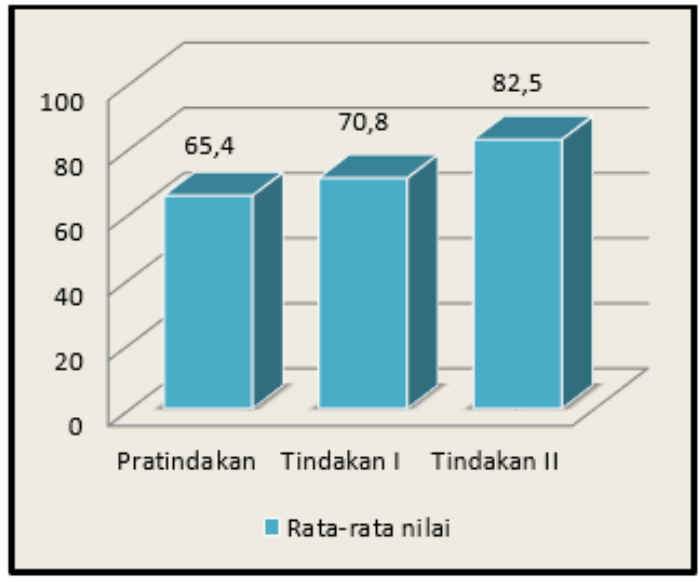

Gambar 6. Rata-rata Nilai Prestasi Belajar Siswa Pratindakan, Tindakan I dan Tindakan II 


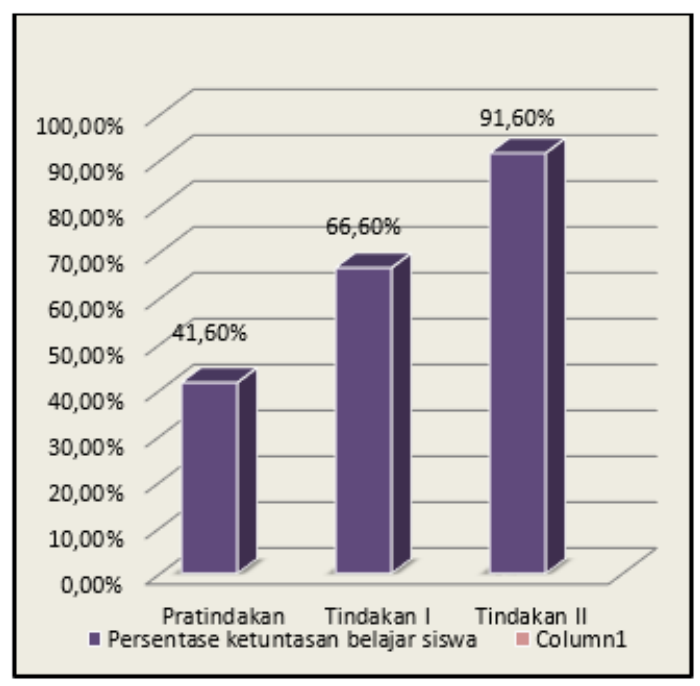

Gambar 7. Persentase Ketuntasan Prestasi Belajar Siswa Tindakan I dan Tindakan II

Hasil angket respon siswa rata-rata menjawab dengan skor rata-rata 2 sampai 3. Hal ini dapat disimpulkan bahwa banyak siswa yang merespon positif. Skor pertanyaan pada angket mulai 1 sampai 8 rata-rata paling rendah yaitu mendapatkan skor minimal 2,5 dengan skor maksimal 3. Dengan demikian disimpulkan bahwa sebagian besar siswa sangat senang dengan penerapan strategi pembelajaran Question Students Have (QSH).

Model strategi pembelajaran Question Students Have (QSH) sangat cocok digunakan untuk jumlah siswa yang tidak terlalu banyak dan diterapkan pada materi bangun ruang sisi lengkung. Hal ini dapat dibuktikan dengan antusiasme siswa ketika mengikuti pembelajaran. Siswa mulai percaya diri dalam mengerjakan soal-soal di papan tulis maupun ketika diskusi kelompok, selain itu strategi Question Students Have (QSH) menjadikan siswa lebih percaya diri dalam menuliskan materi yang belum dipahami.

Pembelajaran Question Students Have (QSH) pada materi bangun ruang sisi lengkung meliputi pembukaan, kegiatan inti dan penutup. Pada kegiatan awal atau pembukaan pembelajaran diawali dengan salam dan apersepsi. Pemberian apersepsi ini diharapkan dapat memancing siswa dengan materi yang akan dipelajari dan memancing perhatian siswa terhadap bahan pelajaran yang diberikan. Kondisi ini sejalan dengan pendapat Kaswara (2017:2) bahwa pemberian apersepsi bertujuan untuk memancing perhatian siswa terhadap bahan pelajaran yang akan diberikan.

Guru memberikan motivasi kepada siswa dan menyampaikan tujuan pembelajaran. Motivasi diberikan kepada siswa agar siswa mempunyai minat dan kerja keras dalam menyelesaikan permasalahan yang ada. Sjukur (2012:3) mengatakan bahwa pemberian motivasi dapat menimbulkan minat, perhatian, kerja keras sampai pekerjaan tuntas terselesaikan. Minat dan perhatian siswa dapat menumbuhkan keberanian menyampaikan ide gagasan dan inovatif dalam menemukan strategi penyelesaian (Daton, dkk, 2019). Tujuan pembelajaran disampaikan kepada siswa untuk memberikan informasi materi yang akan dipelajari siswa.

Sebelum pelaksanaan pembelajaran, terlebih dahulu dibentuk kelompok 4-5 siswa dengan kemampuan yang heterogen. Hal ini didukung oleh Nugroho (2009:110) bahwa pengelompokan yang bersifat umum dengan teman yang berbeda latar belakang kebiasaan dan pengelompokan yang dilandasi oleh variasi dengan tingkat kepandaian berbeda disebut kelompok heterogen, kelompok heterogen lebih disukai di dalam pembelajaran.

Masing-masing kelompok diberikan lembar kerja siswa yang berisi permasalahan. Siswa dapat lebih kreatif dalam menganalisis berbagai macam bentuk soal melalui masalahmasalah yang ada pada lembar kerja siswa. Kemudian guru mengorganisasi siswa untuk belajar dalam menyelesaikan masalah pada lembar kerja siswa. Berdasarkan hasil belajar, siswa akan memperoleh pengetahuan untuk merancang pemecahan masalah. Hal ini sependapat dengan Suhendri (2011:31) bahwa belajar berhubungan dengan tingkah laku seseorang terhadap situasi tertentu yang disebabkan oleh pengalamannya secara berulang-ulang dalam situasi tertentu pada 
saat merancang pemecahan masalah.Tahap selanjutnya yaitu membimbing siswa untuk memecahkan masalah. Dalam tahap ini guru hanya membimbing siswa dan berperan sebagai tutor untuk membantu dalam pemecahan masalah. Gintings (2008:210) mengatakan selama siswa melakukan kegiatan memecahkan masalah, guru berperan sebagai tutor yang akan membantu mereka mendefinisikan apa yang mereka tidak tahu dan apa yang mereka perlu ketahui untuk memahami dan memecahkan masalah. Tahap selanjutnya yaitu membantu siswa dalam menyiapkan hasil karya. Dalam tahap ini, guru menunjuk kelompok secara acak untuk mempresentasikan hasil karya. Presentasi kelompok dimaksudkan untuk mengetahui hasil diskusi yang telah dilakukan. Sebagai anggota kelompok setiap siswa harus mempertanggung jawabkan hasil kelompoknya untuk dipresentasikan. Hal ini sesuai dengan pendapat Djamarah (2010:189) bahwa guru harus meminta pertanggung jawaban anak didik atas kegiatan dan keterlibatan dalam suatu kegiatan, misalnya dengan meminta kepada anak didik untuk memperagakan, melaporkan hasil dan memberikan tanggapan. Pada tahap terakhir, peneliti bersama siswa menganalisa hasil pemecahan masalah yang disajikan untuk mendapatkan kesimpulan jawaban yang benar.

Selanjutnya guru memberikan strategi pembelajaran Question Students Have (QSH). Adapun langkah-langkah strategi pembelajaran Question Students Have (QSH) yaitu guru membagikan potongan kertas kosong kepada masing-masing siswa. Kemudian guru meminta siswa untuk menulis satu pertanyaan yang berkaitan dengan materi yang telah disampaikan. Masing-masing siswa diminta untuk menuliskan pertanyaan, selanjutnya potongan kertas tersebut diberikan kepada teman sebelahnya untuk diberi tanda centang jika pertanyaan tersebut juga ingin ditanyakan dan jika tidak, siswa diminta memberi tanda strip, potongan kertas tersebut diputar sampai kembali pada pemiliknya. Guru memberi waktu pada masing-masing kelompok untuk menghitung jumlah tanda centang pada potongan kertas, untuk tanda centang yang terbanyak mendapatkan prioritas utama untuk dijawab. Selanjutnya guru meminta siswa untuk mengumpulkan potongan kertas tersebut dan membacakan pertanyaannya. Setelah pertanyaan dibacakan, guru memberikan waktu kepada siswa untuk berdiskusi, selanjutnya guru menunjuk salah satu kelompok untuk menjawab pertanyaan. Jika kelompok yang ditunjuk tidak dapat menjawab pertanyaan, maka diperbolehkan kelompok lain untuk menjawab. Guru memberikan nilai untuk siswa yang dapat menjawab pertanyaan tersebut. Siswa diberikan kebebasan untuk menjawab pertanyaan. Kebebasan dalam mengungkapkan ide penyelesaian atas masalah matematika merupakan kesempatan kepada siswa untuk bereksplorasi secara kreatif guna mendapatkan selesaian yang tepat (Hariyani, 2016). Pada kegiatan penutup, siswa menyimpulkan bersama dengan peneliti. Selanjutnya peneliti mengevaluasi jalannya diskusi, memotivasi siswa untuk rajin belajar, dan menginformasikan materi yang akan dipelajari pada pertemuan yang akan datang sehingga siswa bisa mempersiapakn materi dari rumah. Jadi pada saat di sekolah siswa sudah siap untuk belajar.

Hasil aktivitas guru pada tindakan I pertemuan 1 mendapat persentase $81,81 \%$ dan pada pertemuan 2 mendapat persentase 84,37\%. Pada tindakan II pertemuan 1 mendapat persentase $84,09 \%$ dan pada pertemuan 2 mendapat persentase 87,50\%. Aktivitas siswa pada tindakan I pertemuan 1 mendapat persentase $77,27 \%$ dan pada pertemuan 2 mendapatkan persentase $78,12 \%$. Pada tindakan II pertemuan 1 mendapat persentase $81,81 \%$ dan pada pertemuan 2 mendapat persentase $86,66 \%$. Berdasarkan persentase rata-rata nilai aktivitas guru dan siswa pada tindakan I dan tindakan II dalam proses pembelajaran dengan menerapkan strategi Question Students Have (QSH) sudah mencapai kriteria yang ditetapkan oleh peneliti yaitu 75\%. Menurut Djamarah (2010:108) persentase aktivitas guru dan siswa sangat baik dengan rentangan $76 \% \leq \mathrm{NR} \leq 100 \%$. 


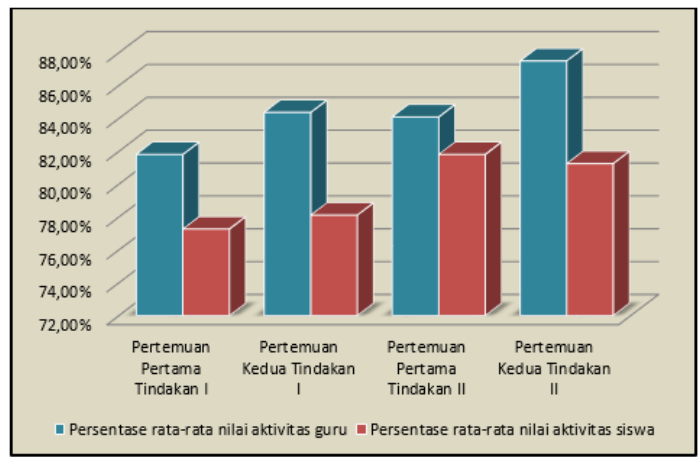

Gambar 8. Aktivitas guru dan siswa tindakan I dan tindakan II

Berdasarkan hasil analisis hasil belajar siswa diperoleh nilai rata-rata hasil tes siswa pra tindakan adalah 65,4 dengan persentase ketuntasan belajar mencapai 41,6\%. Hal ini belum mencapai kriterian yang ditetapkan. Pada pembelajaran dengan menerapkan strategi Question Students Have (QSH) pada tindakan I terdapat adanya peningkatan prestasi belajar siswa. Nilai rata-rata prestasi belajar siswa pada tes akhir tindakan I adalah 70,8 dan persentase ketuntasan belajar mencapai $66,6 \%$. Dari 12 siswa, ada 8 siswa yang tuntas belajar yaitu mendapat nilai $\geq$ 75 dan 4 siswa belum tuntas belajar. Pada tes akhir tindakan II rata-rata nilai ketuntasan pada tindakan II mencapai 82,5 sedangkan persentase ketuntasan pada tindakan II mencapai 91,6\%.

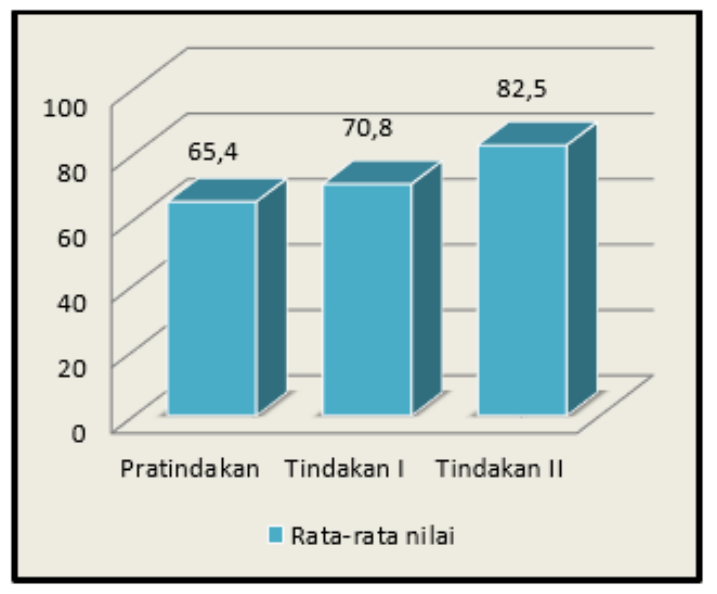

Gambar 9. Rata-rata prestasi belajar Pra tindakan, tindakan I dan tindakan II

Dari hasil aktivitas siswa, aktivitas guru dan prestasi belajar siswa tindakan II dapat disimpulkan bahwa penerapan strategi pembelajaran Question Students Have (QSH) dapat meningkatkan prestasi belajar siswa kelas IX SMPN 2 Karangploso Satu Atap pada materi bangun ruang sisi lengkung.

\section{PENUTUP}

Dari hasil analisis data dan pembahasan hasil penelitian, maka dapat disimpulkan bahwa penerapan strategi pembelajaran Question Students Have (QSH) dilakukan dengan tahaptahap sebagai berikut: tahap awal penelitian ini dimulai dengan penyampaian apersepsi dengan menstimulasi siswa, memotivasi dengan memberikan contoh manfaat materi bangun ruang sisi lengkung dan tujuan pembelajaran. Tahap inti pada penelitian ini dimulai dengan orientasi siswa terhadap masalah, mengorganisasi siswa untuk belajar, membimbing penyelidikan individual dan kelompok dengan cara berkeliling, mengembangkan dan menyajikan hasil karya, menganalisis dan mengevaluasi proses pemecahan masalah, dan pemberian strategi pembelajaran Question Students Have (QSH).Pada tahap ini peneliti memberikan strategi Question Students Have (QSH)untuk evaluasipembelajaran. Pada tahap akhir peneliti memberikan tes akhir yang diberikan untuk mengetahui tingkat pemahaman siswa setelah mengikuti pembelajaran. 
Adapun hasil analisis data dalam penelitian ini yaitu nilai rata-rata hasil tes siswa pada tindakan I mencapai 70,8 dengan persentase ketuntasan $66,6 \%$. Sedangkan pada tindakan II diketahui bahwa nilai rata-rata hasil tes siswa mencapai 82,5 dengan persentase ketuntasan 91,6\%. Hasil aktivitas siswa pada tindakan I pertemuan 1 mendapat persentase 77,27\% dan pada pertemuan 2 mendapatkan persentase 78,12\%. Pada tindakan II pertemuan 1 mendapat persentase $81,81 \%$ dan pada pertemuan 2 mendapat persentase 86,66\%.Sedangkan hasil aktivitas guru pada tindakan I pertemuan 1 persentase $81,81 \%$ dan pada pertemuan 2 mendapatkan persentase $84,37 \%$. Pada tindakan II pertemuan 1 mendapat persentase $84,09 \%$ dan pada pertemuan 2 mendapat persentase $87,50 \%$. Jadi dapat disimpulkan bahwa penerapan strategi Question Students Have (QSH) dapat meningkatkan prestasi belajar siswa.

Disarankan kepada guru matematika menjadikan pembelajaran dengan strategi Question Students Have (QSH) sebagai salah satu altenatif strategi pembelajaran. Sedangkan bagi peneliti selanjutnya disarankan untuk mengembangkan dan menerapkan strategi pembelajaran Question Students Have (QSH) pada mata pelajaran yang lain.

\section{DAFTAR PUSTAKA}

Aminudin. 2017. Penerapan Model Pembelajaran Kooperatif Tipe Question Students Have (QSH) untuk Meningkatkan Hasil Belajar Matematika Materi Pengukuran pada Siswa Kelas IV, Unublitar,1 (2): 434-440.

Arikunto, dkk. 2010. Penelitian Tindakan Kelas. Jakarta: PT Bumi Aksara.

Bahri, A. dkk. 2012. Penerapan Strategi Pembelajaran Aktif Question Student Have dan Kemampuan Akademik Terhadap Hasil Belajar Kognitif Siswa Kelas VIII SMPN 2 Camba, Sainsmat, 1 (1):41-51.

Daton, Y.L, Hariyani, S, \& Suwanti, V. 2019. Penerapan Model Pembelajaran Realistic Mathematic Education (RME) Untuk Meningkatkan Hasil Belajar Siswa. Seminar Nasional FST Universitas Kanjuruhan Malang, Volume 2: 417 - 425.

Djamarah, Bahri, S dan Zain, A. 2010. Strategi Belajar Mengajar. Jakarta: Rineka Cipta.

Gintings, A. 2008. Esensi Praktis: Belajar dan Pembelajaran. Bandung: Humaniora.

Hariyani, S. 2016. Konstruksi Konsep yang Dikaitkan dengan Kreativitas Siswa dalam Menyelesaikan Masalah Matematika, Prosiding Seminar Nasional Pendidikan Matematika:1078-1088

Kaswara, I. dkk. 2107. Pengaruh Pemberian Apersepsi Kemampuan Dasar Matematika Terhadap Kemampuan Siswa Menyelesaikan Soal Kesetimbangan Benda Tegar, Pendidikan dan Pembelajaran, 10 (2): 1-15.

Mulawakan, F. A. 2018. Efektivitas Pembelajaran Matematika Melalui Metode Question Students Have (QSH) Setting Kooperatif, Unismuh, 1 (1): 22-35.

Nisa, I. 2015. Penerapan Strategi Pembelajaran Question Student Have (QSH) Pada Materi Sistem Pertahanan Tubuh Untuk Mengetahui Hasil Belajar Peserta Didik, Program Studi Pendidikan Biologi, 5 (1): 1-10.

Nugroho. dkk. 2009. Penerapan Pembelajaran Kooperatif Tipe STAD Berorientasi Keterampilan Proses, Pendidikan Fisika Indonesia, 5 (2):108-112.

Ramdhani, A. M. 2014. Lingkungan Pendidikan dalam Implementasi Pendidikan Karakter, Pendidkan, 8 (1): 28-37.

Sjukur, S. B. 2015. Pengaruh Blended Learning Terhadap Motivasi Belajar dan Hasil Belajar Siswa Tingkat SMK, Pendidikan Vokasi, 1 (1): 1-15.

Suhendri, H. 2011. Pengaruh Kecerdasan Matematis Logis Dan Kemandirian Belajar Terhadap Hasil Belajar Matematika, Formatif, 1 (1): 29-39.

Vianata, H. 2012. Pengaruh Model Pembelajaran Question Student Have Terhadap Hasil Belajar Sejarah Siswa, Of History Education, 1 (1): 1-5.

Yusri, R. 2015. Penerapan Strategi Question Students Have dalam Pembelajaran Matematika pada Siswa Kelas X SMAN 9 Padang, Lemma, 2(1): 12-20. 